\title{
Archiving the First World Festival of Negro Arts \\ (Dakar 1966): recuperation, nostalgia and utopianism
}

\author{
David Murphy \\ University of Stirling
}

Keywords: festivals; archive; performance; nostalgia; African Renaissance

\begin{abstract}
This article will examine the concepts of recuperation, nostalgia and utopianism in relation to the First World Festivals of Negro Arts, which was held in Dakar in 1966, in part through an exploration of how this event was evoked in the third edition of the festival (known as FESMAN) in 2010. It will address a series of intriguing questions about the difficulties involved in locating an archive of ephemeral, performance-based events, which may leave few material traces after they have been completed. Although the major PanAfrican cultural festivals of the 1960s are regularly cited (usually in passing) as key illustrations of the utopianism that marked the period of decolonization, the issue of their actual legacy in terms of popular, institutional and official national memory is a complex one. The first half of the article will thus explore the official archive of the 1966 festival, while also attempting to identify new ways of engaging with some of its legacies for its multiple audiences. The second half of the article will then explore what FESMAN 2010 reveals about the prevalence of processes of recuperation and nostalgia, but also the on-going utopian engagement with the Pan-African archive in contemporary engagements with these ephemeral events from the past.
\end{abstract}


From 10-31 December 2010, Dakar, the capital of Senegal, hosted the Troisième Festival Mondial des Arts Nègres (translated into English as Third World Festival of Black Art and Culture, but more commonly referred to simply as FESMAN), which took for its main theme the notion of an 'African Renaissance'. The primary architect of FESMAN was Abdoulaye Wade, the octogenarian Senegalese President. During his time in office-he finally lost power in 2012 after 12 years as head of state-Wade had attempted to position himself both politically - through his membership of the steering group at the head of NEPAD, the New Programme for African Development - and culturally-through the organization of FESMAN and the construction of the controversial Monument of the African Renaissance (figure 1) - as the central figure in the revival of a utopian pan-Africanism. The idea of an African Renaissance had emerged from post-apartheid South Africa in the 1990s, and had subsequently been adopted by Wade as the early years of the new millennium marked a period of rapid and sustained growth in numerous countries across the continent. But by the time the festival took place, the world was in the midst of a global financial crisis and economic growth had stalled: the glorious renaissance envisaged by Wade appeared, at the very least, to have been postponed.

The evocation of an African Renaissance was, of course, not entirely new when adopted by the likes of Wade and South African President, Thabo Mbeki, in the 1990s. As far back as the 1920s, Marcus Garvey had called upon Africa and the black world more generally to awaken from its slumber and to stake its place on the world stage. Such calls had grown louder in the immediate decades after World War Two during which Pan-Africanist sentiment-the feeling that Africa and its diaspora working together could restore the continent to its former glory-reached its peak. The period extending from the late 1950 s to the mid-1970s witnessed the creation of a wide range of Pan-Africanist political structures- 
in particular, the Organization of African Unity, now the African Union-while many cultural gatherings/festivals (as well as sporting events) informed by Pan-Africanist ideals were also held, not least the First World Festival of Negro Arts that took place in Dakar from 1-24 April 1966. This international forum showcased a wide array of arts and was attended by such celebrated luminaries as Langston Hughes, Duke Ellington, Josephine Baker, Aimé Césaire, André Malraux and Wole Soyinka. Described by its principal architect, Senegalese President Léopold Sédar Senghor, as 'the elaboration of a new humanism which this time will include all of humanity on the whole of our planet earth' (cited in Flather 1966, 57), the festival sought to emphasize the significance of culture and the arts in defining a global role for Africa in the aftermath of empire. ${ }^{1}$

From Wade's perspective, organizing FESMAN involved a process of looking to the future but also of renewing with an idealistic, utopian Pan-Africanist past, which was primarily articulated through evocations of the 1966 Dakar Festival. This article will examine the extent to which processes of recuperation, nostalgia but also utopianism might be seen to be at work in this twenty-first century attempt to engage with the idealism of the $1960 \mathrm{~s}$. However, it does not operate from the assumption that the contemporary period is somehow uniquely compromised by a nostalgic approach to the past. If Wade had one eye on the past while looking to the future, then so too did Senghor in the 1960 s, for the 1966 festival paradoxically evoked classical antiquity and postcolonial modernity in the same breath. In effect, as I have argued elsewhere (see Murphy 2015; 2016), Senghor sought to 'perform', through his writing and through the festival, an African renaissance, to define an African classical age that might act as an inspiration for the future. In the years immediately following independence, the desire to imagine a unified Pan-African future, predicated on a glorious past seemed entirely understandable but what did such a vision mean in 2010? Could 
the 2010 edition of the festival ever be anything more than a rather belated gesture? Or does such a question imply a stance that is simultaneously too critical of FESMAN 2010 and too indulgent towards the 1966 event?

The article will address a series of intriguing questions about the difficulties involved in locating an archive of ephemeral, performance-based events, which may leave few material traces after they have been completed. Although the festivals of the 1960 s are regularly cited (usually in passing) as key illustrations of the utopianism that marked the period of decolonization, the issue of their actual legacy in terms of popular, institutional and official national memory is a complex one. Is it feasible to identify the specific impact and legacy of an event such as the 1966 festival in terms of cultural practices, influences and the creation of real and imagined networks of cultural actors and scholars? And what exactly do we mean when we refer to the archive of Dakar 1966? The national archives in Dakar hold the papers of the 1966 festival organizing committee but these necessarily reveal only a partial image of the event: they seek to promote an officially sanctioned view of its significance and meaning, and can only hint at the ways in which the event communicated with and influenced its audiences. The festival organizers were clearly aware of this themselves and the beautifully produced official record of the festival contained summaries of various live performances which obviously could only hint at the precise nature of the performance and its reception by the audience (Premier festival 1967). Consequently, the first half of the article will briefly trace the official archive of the festival and the ways in which it sought to engage with a certain understanding of the archive of Euro-African history. I will then try to identify other methods of engaging with the Dakar festival as a way of beginning to understand its complex legacies for some of its multiple audiences. 
The second half of the article will explore what FESMAN 2010 reveals about the prevalence of processes of recuperation and nostalgia, but also the on-going utopian engagement with the Pan-African archive, including an idealized version of the 1966 festival, in contemporary engagements with ephemeral events from the past. Pan-African political unity may be a distant prospect but that does not mean that attempts to achieve such unity or to imagine a transnational black culture at FESMAN or in other contexts are somehow misguided, for, as Tsitsi Jaji writes in Africa in Stereo, her fascinating exploration of transAtlantic musical encounters, 'pan-Africanism is no bogus attachment' $(2014,11)$. Consequently, this article is 'at work in the archive' in large part in order to trace the cultural and political energy of the Pan-Africanism of the 1960s-70s, and to explore whether this has survived into the contemporary period. Can we interpret the 1966 Dakar festival as an archive of Pan-Africanism and, if so, how then might we understand FESMAN 2010's engagement with that archive?

\section{Research Context}

The recent rise of 'festival studies' as a field of inquiry has led to a growing academic interest in the wave of cultural festivals that have now spread across the African continent, and more widely (see Dovey 2015). However, despite the overwhelming success of the Dakar festival and the subsequent Pan-African festivals in Algiers and Lagos, the international festivals of the 1960s and 1970s, which celebrated a global black culture, have received surprisingly little sustained critical attention. The one major, book-length study to have appeared in this field is Andrew Apter's The Pan-African Nation, which examines the politics of FESTAC '77, in Nigeria, which was explicitly billed as the successor to Dakar 1966. Basically, Apter seeks to explore how the postcolonial Nigerian state, flush with oil revenues, attempted to project a 
Pan-African culture that was truly global but that positioned Nigeria as the centre of this culture: 'Nigeria's black and African world was clearly an imagined community, national in idiom yet Pan-African in proportion, with a racialized sense of shared history, blood and culture' $(2005,6)$. Although Apter began the project by reading FESTAC as the antithesis of colonial exhibitions, he soon found a more complex set of relationships between the exhibitionary practices of the colonial and postcolonial periods: '[FESTAC's] [a]rtistic directors and cultural officers invented traditions with precolonial pedigrees. [...] [I]n a fundamental sense, the customary culture which FESTAC resurrected was always already mediated by the colonial encounter, and in some degree was produced by it' (Apter 2005, 6).

The context in Dakar in 1966 was in certain respects rather different-Senegal was a small country, with no oil boom to boost its economy or self-esteem-but it witnessed similar attempts to project a 'new' Pan-African culture predicated upon rather problematic colonialera notions of racial and ethnic identity. Unlike Nigeria, the festival was primarily associated with the creative vision of one individual, namely, Léopold Sédar Senghor, ${ }^{2}$ who envisioned the event as the embodiment of his own poetic and philosophical reflections on the creation of a 'Universal Civilization' in which 'black' culture would once again (after centuries of slavery and colonization) have a central role to play. How then did Senghor's festival turn to the past in order to perform a Pan-African culture of the future?

\section{The Archive and Dakar 66}

Léopold Senghor, Alioune Diop and the other 1966 festival organizers clearly gave great thought to ensuring that an officially approved archive of the 1966 event was created. A festival handbook/programme was published in advance (figure 2) and a handsomely produced official commemorative volume was released later in the year (Premier festival 
1966, 1967). In 2001, the Senegalese state archives created a brochure providing a detailed breakdown of the contents of 48 box files of archives relating to the organization of the 1966 festival. The event was very much organized with one eye on posterity: for, as Derrida argued, the archive is always concerned with the future (Derrida 1996). Each of the major Pan-African festivals of the 1960s-70s promoted a transnational identity and culture but they also acted as striking examples of the postcolonial African state's desire to assert its own modernity. The postcolonial state carefully archived the paperwork from the planning stages of these mega-festivals, which was proof, they believed, of the their bureaucratic modernity, but, just as importantly, the festival programme itself - the list of performers and artworks gathered together in one place at a given moment in time- - was seen to constitute a form of archive: the programme was the result of specific choices regarding which art forms and which performers merited a place in the 'archive' of Pan-Africanism. The 1966 festival organizers thus created an institutional archive but also mobilized the important metaphor of the event itself as an archive hosting the 'best' in black culture both past and present.

What then do we find in the official archive of Dakar 1966? What memory of the event did Léopold Senghor and his colleagues wish to pass on to posterity? A US visitor to the Dakar Festival, Newell Flather, wrote of his impressions a month later in Africa Report (May 1966):

Visitors to the First World Festival of Negro Arts in Dakar had an exhilarating immersion in the sights and sounds of Africa and the Negro World, of the old and avant-garde in dance and drama, poetry and painting. Dr Léopold Sédar Senghor, President of Senegal and principal architect of the festival, told the audience on opening night that its purpose was the 'defense and illustration of negritude' - 'the elaboration of a new humanism which this time will include all of humanity on the whole of our planet earth'. (Flather 1966, 57) 
Senghor's reference here to the 'defense and illustration of negritude' captures the ambiguity of his celebration of blackness: the work of Joachim Du Bellay (2015 [1549]), the defender of a vernacular French against the then dominant cultural and scientific language of Latin in sixteenth-century France, is invoked to illustrate the role of Negritude. For Senghor, the future of Francophone Africa lay in a Franco-African cultural hybridity of which he and his fellow évolués would serve as a sort of avant-garde, bridging the divide between Negritude and francité (that is, between blackness and Frenchness) and somehow combining these to forge a 'Universal Civilization'. The reference to DuBellay also signals the parallels that Senghor draws between what he views as the current African renaissance and the European renaissance several centuries earlier: it is through an increased awareness of the cultural greatness of the past that a great, modern culture will emerge. The classics constituted the archive of western civilization, and, through his writings on Negritude as a deeply rooted expression of African cultural identity, Senghor sought to build a comparable African archive that might inspire a golden future for the continent. If the source of contemporary European civilization was to be found in Greece and Rome, then a postcolonial Africa would be built on the foundations laid by a shared black culture whose ancient roots were, in the midtwentieth century, being gradually uncovered by archaeologists, one of whom, the Jesuit mystic Pierre Teilhard de Chardin, greatly influenced Senghor's thinking. ${ }^{3}$ The 1966 festival was thus, as Denis Ekpo has argued in relation to FESTAC 77 in Lagos, 'all of the grand theories of a black/African cultural/racial renaissance exhumed from the literature' and 'performed live on the world stage' (Ekpo 2008, 28).

The festival was planned and celebrated as the apotheosis of Negritude but some of the main prize winners at the festival-Wole Soyinka, Tchicaya U'Tamsi and Ousmane Sembene-were in fact vociferous opponents of Negritude as a concept. In particular, the 
success of Sembene's work (he won literary and film prizes) created something of a problem in this respect. For example, in the June 1966 edition of the monthly Francophone West African cultural magazine Bingo, Paulin Joachim engaged in a less than subtle process of recuperation in his ambiguously titled editorial, 'Negritude, never heard of it' (Joachim 1966a). He claims that Sembene (as well as Soyinka and U'Tamsi) had been forced to see the error of his ways, as though winning prizes at what he explicitly views as a Festival of Negritude is clear evidence of their false consciousness. Essentially, for Joachim, the Festival was the real enactment of the metaphorical process often evoked by Senghor in relation to Negritude, that of storing Africa's 'soul' in a safe place in order to meet the challenges of a future globalized world (Joachim 1966b). Joachim's desire to gloss over the success of Negritude's opponents in the arts competitions sponsored by the Festival is highly problematic precisely because it seeks to erase any sense of the contemporary postcolonial concerns of Soyinka, U'Tamsi or Sembene. Although Senghor saw the Festival as the embodiment of his conception of an emerging Pan-African culture and the expression of Negritude, the prizes awarded to the socially and politically committed fiction of Sembene illustrated the extent to which rival visions of African culture were already coming to the fore. ${ }^{4}$

As was noted above, through the 1966 festival, Senghor was essentially seeking to 'perform' an African renaissance, to define an African classical age that might act as an inspiration for the future. Here, we witness once again the power of the archival metaphor: for, the staging of the event would, in itself, produce a canon of 'great' works and performers to which later generations must refer. This process was particularly evident in the major exhibition of Negro Art, held at the newly built Musée Dynamique, which Senghor viewed as the 'heart' of the festival. It drew together over 600 objects from Africa's 'archive' of 
'classical' artwork, borrowed from museums and private collectors around the world. In speeches made prior to the Festival, Senghor made remarkable comparisons between contemporary Senegal and ancient Greece, which underlined his homeland's classical heritage, the source of its current and future vocation at the heart of an emerging Universal Civilization:

The Greeks lived in a poor country of narrow plains and rocky hills. But, like the Senegalese people, they had the sea beside them, cereals on the plains, oil in the hills and marble in the soil. [...] They sacrificed everything for the love of liberty and truth, for the love of life and beauty. They lovingly cultivated literature and the arts [...], mathematics and philosophy. That's why, as long as Men are alive on this planet, they will speak of Greek civilisation as a world of light and beauty. (Speech to Senghor's UPS party in January 1966; cited in Rous 1967, 76-77)

Senghor's soaring rhetoric was no doubt far-removed from the day-to-day concerns of many of his people, although it is entirely consistent with the profound idealism of the era of decolonization that he was able to imagine such a vision for a newly independent, small country on the westernmost tip of Africa. Also, despite Senghor's love for abstraction and the longue durée, he could support his claims by pointing to some hugely impressive diplomatic and practical achievements (not least the exhibition at the Musée Dynamique) in enabling the festival to take place at all.

In its complex mix of the utopian and the pragmatic, the First World Festival of Negro Arts was thus a striking example of the approach that Gary Wilder has identified as central to the postwar thought of both Senghor and Aimé Césaire. Although Wilder focuses on the period from 1945-60, and the ultimately failed attempt to construct a federal solution that would tie France to its former colonial possessions - in what he calls 'pragmatic-utopian visions of self-determination without state sovereignty' (Wilder 2015, 7) — his analysis seems 
equally applicable to their (similarly fraught) attempt through the festival to construct a transnational black community:

[Césaire and Senghor's] projects were at once strategic and principled, gradualist and revolutionary, realist and visionary, timely and untimely. They pursued the seemingly impossible through small deliberate acts. As if alternative futures were already at hand, they explored the fine line between actual and imagined, seeking to invent sociopolitical forms that did not yet exist for a world that had not yet arrived. (Wilder $2015,2-3)$

Wilder's reading of Senghor's and Césaire's transnational political imagination in the postwar period invites us to look beyond the 'failures' of their project and its perceived lack of realism. Their willingness to imagine a post-imperial world outside the confines of the nation state or the hegemony of Western imperialism may ultimately have been unsuccessful but it offered models and ideas - a commitment to transnational forms of community, and a focus on culture as the best way to forge that community - that continue to inspire many black people both in Africa and the diaspora: in essence, these models and ideas constitute an archive that can be revisited in order to imagine alternative futures for the continent and its relationship to the 'black world'. The archive of Pan-Africanism is not fixed; it is constantly available for later generations to re-interpret.

\section{The archive of pan-Africanism (not Pan-Africanism)}

Approaching the 1966 festival in the way this article has done thus far is, in many respects, to adopt the 'classic' archival approach, which prioritizes analysis of the official records and the 
words of high-placed officials: this is the archive as preserved by the powers-that-be, a partial record that presents itself as all that can and should be remembered of an event or period. Most scholars have long been conscious of the partial nature of the official archive and have sought to explore other sources (e.g. through oral history projects) that might counter-balance them. The reliability of the archive seems particularly problematic in the case of a major festival, which is an event comprised of a series of performances that involve the participation of thousands of cultural actors and spectators. As Dominique Malaquais and Cédric Vincent argue, 'official archives mostly end where the festivals they concern begin' (Malaquais and Vincent 2016: XX). The official archive records what the organizers intended but what did the festival mean to those who experienced it? What is the legacy of a festival for its various participants and audiences? How might we complement the official, state archive through engagement with other archival sources?

While the 1966 festival (like the other mega-festivals of the 1960s and 70s that followed) was in large part driven by a national government keen to promote the officially sanctioned account of its relevance and significance, various cultural actors, performances and works of art refused to confirm to the dominant ideological narrative, despite careful attempts to police festival programming. Bringing together thousands of participants and audience members inevitably gave rise to a series of personal encounters the narrative of which simply could not be regulated by the Senegalese state or other supporters of Negritude. The encounters generated when thousands of cultural actors are brought together in one city can often take highly unexpected forms. For example, Hélène Neveu Kringelbach (2016) charts the 'popular cosmopolitanism' of the dance parties and street events at Dakar 66, while Tsitsi Jaji (2016) traces non-elite accounts of the festival in popular magazines. In the process, both authors recover the voices of female participants (mainly dancers) in the 
festival, whose stories are often occluded in the official archive. Neveu Kringlebach also notes the impact on individual Senegalese dancers of witnessing the modernity of the Alvin Ailey dance troupe's performances, which would in turn influence their vision of African dance.

The 1966 Dakar festival facilitated concrete encounters between Africans and members of the diaspora that forged a new and profound sense of cultural belonging. For instance, in his autobiography, Music is my Mistress (1973), the great US jazz musician Duke Ellington wrote of the warm response to his performances in Dakar in 1966: 'the cats in the bleachers really dig it. You can see them rocking back there while we play. When we are finished, they shout approval and dash for backstage where they hug and embrace us, some of them with tears in their eyes' (Ellington 1973, 338). Ellington's encounters with ordinary Africans ('the cats in the bleachers') and the friendship he developed with Senegalese painter, Pape Ibra Tall, constitute instances where the official discourse of Negritude was forced to negotiate with the lived experience of real people. The festival elicited in Ellington a desire to communicate on a personal and cultural level with Africans: in preparation for the event, he had even composed a new song, 'La Plus belle Africaine' and, as his son (a trumpeter in his father's band), told the Los Angeles Times, 'Sam Woodyard, our drummer, was a big hit. [...] He's spent a lot of time studying African rhythms, so the natives got a big kick out of hearing their own licks come back home. ${ }^{5}$ In addition to these individual examples, the American Society for African Culture had chartered a plane taking over 200 visitors to Dakar for the festival and one can only guess at the numerous personal encounters to which this gave rise. At the dawning of the jet age, Africa was now, for the first time, within easy reach for an emerging African-American middle-class. 
In this context, Jaji's recent work on trans-Atlantic musical dialogue has provided a timely reminder of the distinction that George Shepperson drew over 50 years ago between 'Pan-Africanism' and 'pan-Africanism': the former refers to the formal international gatherings and organizations of the 'Pan-Africanist' movement since 1900 while '[s]mall "p" pan-Africanism designates an eclectic set of ephemeral cultural movements and currents throughout the twentieth century ranging from popular to elite forms' (Jaji 2014, 3). The 1966 Dakar Festival was a Pan-Africanist event but it was one at which the performance of pan-Africanism, in terms of personal encounters and exchange around cultural forms was able to flourish.

Over the past few years, a research project (on which I have collaborated), PANAFEST Archive, based at the Ecole des Hautes Etudes en Sciences Sociales in Paris, has sought to excavate a new archive for each of the four great pan-African festivals of the 1960s-70s (Dakar '66; Algiers '69; Kinshasa '74; Lagos '77). It began by consulting the 'official', institutional archives of these festivals (where these exist) and now, in a second phase, has shifted from macro- to micro-history via the stories of individual participants from each of the four events. Filmed interviews with participants already feature on the project website alongside elements of the official archive. In February 2016, the project team launched an exhibition at the Quai Branly Museum in Paris, Dakar 66: Chronicle of a Pan-African Festival (16 February-15 May 2016), to coincide with the $50^{\text {th }}$ anniversary of the Dakar event. ${ }^{6}$ The exhibition blurb explicitly states that the intention is not to create a minute record of how the festival was planned and how it unfolded, but rather to trace the visual representations of the event and how these can be mobilized to support different interpretations of it. This approach is reinforced by the use of filmed interviews with participants in the festival which highlight the lived experience of individual actors as well as 
personal encounters that occurred in the midst of what might appear to have been a monolithic 'mega-event'. The desired effect is to make the exhibition an open-ended, living reflection on a landmark event in the history of decolonization. ${ }^{7}$ Such an archive is of course open to nostalgia and recuperation but its very nature means that it should not fall victim to the aporia that Derrida characterizes as central to the official archive, which claims to record the past for the future but can only ever capture selective elements of that past.

\section{FESMAN 2010: recuperation, nostalgia, amnesia}

As was outlined above, the 2010 festival explicitly positioned itself in relation to its predecessor (figure 3). This direct link to Léopold Senghor and the 1966 event was made manifest during the opening ceremony of FESMAN on 10 December at the national football stadium, the (aptly named) Stade Léopold Sédar Senghor. One entire stand had been employed as a giant screen onto which was projected a series of animated images designed to relate several centuries of African history in a narrative devised by the black British playwright Kwame Kwei-Armah (a narrative echoed on the pitch by hundreds of choreographed dancers). As a prelude to this history, Senghor appeared on screen (framed in a retro wooden tv screen) in archival footage of a speech from what appeared to be the opening ceremony of the 1966 festival. In typically academic style, Senghor's speech engaged with the essence of l'art nègre, as the expression of a mode of perception and understanding of the world rooted in the spiritual, the natural, the physical, all of the usual components of black identity that were central to Senghorian Negritude. Indeed, echoes of Senghor were present all through the festival, and the use of this clip encapsulated the inherently ambiguous process at the heart of FESMAN 2010. The festival was deemed a direct sequel to the 1966 event with Wade presented as heir to his predecessor's mantle as 
great Pan-Africanist, but the desire to hark back to 1966 also revealed an anxious form of recuperation in which the past was called upon in order to lend weight to Wade's cultural endeavour. Where Senghor had been the pioneer, hosting the first ever festival mondial des arts nègres, Wade was the host of the third such festival (as was mentioned above, the second had been held in Lagos in 1977) and was conscious that he might thus be perceived as belatedly attempting to revive a cultural moment whose time had long since passed.

Throughout his presidency, Wade regularly sought to engage with the past in ways that would signal both his own historical rootedness and longevity (he was finally elected President in his 70 s after five failed election campaigns). This was a man who had taken part in the legendary Congress of Black Writers and Artists in Paris in 1956: he can be seen in the iconic group photograph taken in the courtyard of the Sorbonne, off to one side, away from more celebrated peers such as Senghor, Alioune Diop, Aimé Césaire and Frantz Fanon. Wade's presidency offered him a platform from which he could project his vision of a bold African future rooted in a proud African past in which his own role was central. This process can be seen through the construction of the Monument de la Renaissance Africaine, an artistically and ideologically confused paean to the Pan-Africanist cause that Wade claims to have designed personally: the history of Pan-Africanism narrated in the exhibition space within the base of the structure situates the monument, and thus Wade himself, as the terminus of a cultural and political movement to which the likes of Toussaint Louverture, Marcus Garvey and Senghor had contributed. ${ }^{8}$

The 2010 festival thus explicitly cast itself in partially nostalgic terms as a return to the ideals of 1966, and this return took the form of a perhaps inevitable recuperation of Senghor's ideas reshaped to meet Wade's agenda. There was equally a large dose of amnesia involved in the evocation of 1966 on both sides of the political spectrum. For the opposition 
press, this led to the creation of an idealized version of the earlier festival with which to beat Wade: For example, La Sentinelle angrily proclaimed on its front cover on 15-16 December that ' $[\mathrm{t}]$ his is a festival of shame', citing Sérigne Ndiaye Gonzales, a celebrated actor who had performed at the 1966 event (Gonzales 2010) who decried the practical shortcomings of FESMAN 2010 (of which there were many). This sanitized version of the 1966 festival cast it as a flawlessly organized event when in fact many contemporary accounts (particularly those written by foreign visitors) catalogued a series of problems: half-empty venues, unfinished accommodation, technical flaws.

Wade's desire to project continuity revealed a glaring paradox at the heart of FESMAN 2010: for if the 1966 festival had announced the rebirth of Africa on the world stage why exactly was it still necessary 44 years later to proclaim that Africa's cultural renaissance had arrived and that it would inevitably lead to social and economic development? The official stance of FESMAN 2010 was thus in large part marked by nostalgia for an imagined past, whose actual successes, failures and paradoxes were lost from view. Wade turned to the past as an archive from which to imagine a utopian future, although it was a future that that a great number of his many opponents would have deemed dystopian (see De Jong and Foucher 2010). Wade's festival invoked Senghor as a figure of authority and legitimacy but it simultaneously enacted a form of 'archival violence' on the 1966 event by emptying it of its content regarding the nature of a Pan-African culture. This, in many ways, is in keeping with Derrida's vision of archiving as an inherently destructive, archive-destroying process (Derrida 1996, 10).

While the 1966 festival was built on the ideological foundations provided by Senghor's Negritude, FESMAN 2010 had much more diverse ideological moorings which veered between a diffuse sense of a shared Pan-African culture and a far more racialized form of 
Afrocentric thought. As had happened in 1966, FESMAN organized a major conference, clearly designed to be its intellectual centrepiece - the festival programme referred to it as the 'conférence structurante'-in order to articulate an intellectual vision to accompany its cultural celebration. The opening session was chaired by Wade who spoke at great length about the cultural unity of the black world and the need for political unity on the continent, declaring at one point (something he would reiterate in his speech at the opening ceremony later that night) that he would happily become 'Governor of Senegal in a United States of Africa', a claim difficult to believe of a politician who exercised a vice-like grip on power and ran for a third term of office at the age of eighty-six.

I attended the first two days of the 'conférence structurante', but did not manage to gain any clear sense of what speakers understood by the African Renaissance: at times, we were deemed to be living through it, at others we were exhorted to create the policies and forums that would make it a reality. As no publication of the conference proceedings has been published (a major difference from 1966), there has not even been a subsequent attempt to give a unified shape to the various voices heard at the conference. But the most troubling aspect of the conference was the space it allocated to a strand of Afro-centrism that equated African Renaissance with the celebration of a glorious Pharaonic past, and that seemed intent on reducing the work of the great Cheikh Anta Diop to a backward-looking nostalgia (most obvious in the contributions of Théophile Obenga and Runiko Rashidi). It was as though FESMAN had created a bizarre time warp in which the potential dangers of such Afrocentrism (for example, Mobutu's authenticity“ project in 1970s Zaïre) were completely unknown.

FESMAN 2010 also differed greatly from the 1966 event in terms of its understanding of what constituted 'culture'. As the chief theorist of Negritude and a Sorbonne-educated 
intellectual, Senghor had ensured that the 1966 festival would promote the values of an essentially defined 'blackness' and that it would do so through the celebration of high culture (figure 4). In place of Senghor's firm belief in the superiority of an elite, selective, high culture, however, FESMAN celebrated popular culture: it showcased a highly eclectic mix of African arts with a strong emphasis on popular arts, especially pop music, as well as elements of African culture defined far more broadly, including sporting events (figure 5), even workshops on urbanism and architecture, arts and crafts. This difference between the artistic visions of the two festivals involved a wilful amnesia regarding the earlier event: the desire to recuperate the glory of 1966 meant that such 'details' were simply ignored.

There was no official festival document or speech that spelled out exactly what FESMAN 2010 understood by (black) culture. Indeed, imbued with the restless spirit of Wade, the organizers seem to have prioritized 'making lots of stuff happen'. The festival was packed with a bewildering array of events, and, it should be noted, absolutely everything was free to the public. I spent ten days at the festival, during which time I saw a football match between the U-20 teams of Senegal and Brazil (which attracted a crowd of about 20,000 people); I attended a major exhibition of contemporary African art at the Biscuiterie de la Médina (including work by the likes of Yinka Shonibare); there was a rather low-key exhibition of 'traditional' art at the newly renovated Musée national (whereas the traditional art exhibition had been the centrepiece of the 1966 festival); the Ethiopian National Ballet performed at the Maison de la Culture Douta Seck and I returned there the next day for Mondomix's outstanding, high-tech interactive exhibition on black music. Every night, there was a free, open-air concert at the independence monument in Colobane, and huge crowds turned up to see the likes of Youssou Ndour, Salif Keïta, Akon and Diam's. The whole operation was run on-line with no physical festival HQ at which delegates could congregate. 
By any standards, this was an incredibly eclectic festival that sought to engage with a wide range of audiences.

The high tech, decentred and participatory qualities of FESMAN 2010 made it a very different event to the first Dakar festival of 1966. If the latter event was a reflection of the elite-run, one-party state of the decolonization era, then FESMAN 2010 reflected the confusing politics of Wade's Senegal: high tech and decentred it may have been but the festival was also organizationally chaotic; and its democratic tendencies can easily be read as populism and demagoguery (see Murphy 2014). The 1966 festival and its archive were a product of the forms of governmentality of the 1960s African state and its desire to prove its bureaucratic modernity, while FESMAN 2010 and its lack of an official archive were equally a product of their time. Wade's Senegal emerges from the festival as a hybrid ideological mix of dirigiste state intervention sitting uneasily alongside a vaunted free-market spirit: it harnessed the energies of the Internet era and the creative industries but unsuccessfully attempted to shape and contain them within the bounds of an ill-defined state ideology.

It seems almost impossible for there ever to be an official archive of FESMAN. Even the programme and its archival record of who appeared at the festival cannot be trusted, as many of those listed on the printed/on-line programme never appeared. ${ }^{9}$ Although the printed/on-line programme for FESMAN 2010 appears to offer us a record of what happened at this ephemeral event, it is largely a fictitious archive, a comically Orwellian attempt to shape an official version of history. However, although the festival's chaotic organization may have closed off important archival possibilities it also opened the festival to the masses in a way that simply did not occur in 1966. Equally, FESMAN 2010 opened up a potential new archive in the form of the individual testimony of the thousands who attended one or more elements of the festival. The largely elitist 1966 festival attracted an overall audience of 
about 50,000; while some of the larger concerts held at the Colobane independence monument in 2010 attracted an audience of 20,000 on one night alone.

FESMAN 2010 may have lacked a single, guiding philosophy but, in many ways, this is as much a reflection of the contemporary fragmentation or diversity of thought on black culture and identity as a sign of the incoherence of Wade's regime. In addition, as was argued above, the 1966 festival only appears in retrospect to have been a unanimous celebration of Negritude, whereas in fact a conscious process of recuperation had been required to defuse the critiques of the likes of Soyinka and Sembene. Senghor had wanted the 1966 festival to act as a living illustration of Negritude, while the festival's archive had sought to ensure the legacy of that particular vision of the event. However, such control of the archive and of the meaning of Pan-Africanism proved illusory: for, as the PANAFEST Archive team have underlined, archives are 'labile entities fixed neither in space nor time - a definition that accords with the complex, multifaceted and changing nature of Pan-Africanism itself' (Malaquais and Vincent 2016, XX).

I would thus argue that FESMAN 2010 was a flawed but rich and diverse performance of Pan-Africanism, which was responding to the changed landscape of the early twenty-first century. It may have been marked by a recuperative and nostalgic approach to the archive but this did not foreclose the possibility of re-igniting some of the utopian energies identified by Jaji as central to earlier manifestations of the Pan-Africanist project. Shortly after the conclusion of FESMAN, its British artistic director Kwame Kwei-Armah claimed of his experience in Dakar that:

It was like the UN in the artists' village [...]. You sit in the cafeteria and Mauritanians are jamming, the Guadeloupeans are giving impromptu readings — it's artistic heaven. 
Being able to take in the great art, and then being able to chill out with world-class artists with my children has probably been the highlight of my life so far. (KweiArmah, cited in Pool 2011)

FESMAN 2010 thus witnessed the celebration of both Pan-Africanism and pan-Africanism. Its success as a well-organized mega-event may be questioned but it nonetheless provided a forum in which pan-Africanist energies were allowed to flourish.

\section{Conclusion}

One of the most tangible legacies of a major festival such as Dakar 66 is the transformation of the built environment, for a festival is an event that takes place in specific urban spaces, and this often requires construction work that transforms the lived landscape of the city. Theis, too, constitutes a form of archive but, just like the other archival traces this article has examined, its meaning is not fixed. The main permanent structure created for the 1966 festival was the Musée Dynamique. ${ }^{10}$ It was built to house a major exhibition of 'traditional' African art (what Senghor would consider to be the products of Africa's 'classical' age) and, in the decades that followed, it served as Senegal's primary state-owned art museum. Then, suddenly, in 1976, Senghor, took the unexplained decision to hand the museum over to the celebrated choreographer, Germaine Acogny, to house her dance school. In 1980, Senghor, the President as man of culture, retired to be replaced by Abdou Diouf, the President as technocrat. At the same time, in the harsh economic climate introduced by the IMF's Structural Adjustment Programme, state funding for culture was slashed. In the mid-1990s, I travelled to Dakar as a graduate student to carry out research for my doctoral thesis: armed with a 10-year-old map of the city, I set out to visit the Musée Dynamique only to discover 
that it had been converted into the country's Supreme Court by Diouf in 1988 . The fate of the Musée Dynamique serves as a striking example both of the whims of the postcolonial state and of 'labile' nature of all archival traces. As we saw above, for Senghor, the exhibition of Negro Art held at the Musée Dynamique in 1966 had constituted the 'heart' of the festival. But the fact that this iconic building has lost its cultural vocation entirely should remind us that the legacy of the African renaissance so proudly announced by the 1966 festival was not as enduring as the official archive might like us to believe.

From our contemporary perspective, the Pan-African political and cultural initiatives of the 1960s and 70s now appear strikingly utopian. However, the Pan-African ideal has endured at various cultural levels on both sides of the Atlantic and there has been a renewed academic interest in Pan-Africanism over recent years (see, in particular, Amzat-Boukara 2014). Consequently, it is important for us to revisit the First World Festival of Negro Arts not solely for what it tells us about the past but also to understand, in terms that Gary Wilder has outlined in another context, the ways in which the event can be used as a living archive to imagine various utopian futures:

I am not primarily concerned with futures whose promise faded after imperfect implementation nor with those that corresponded to a world, or to hopes, that no longer exist but instead with futures that were once imagined but never came to be, alternatives that might have been and whose unrealized emancipatory potential may now be recognized and reawakened as durable and vital legacies. (Wilder 2015, 16)

The series of cultural festivals in the era of decolonization, of which the Dakar event was the first, constituted some of the most meaningful articulations of Pan-Africanism. In essence, 
the 1966 festival constituted a hugely significant performance of Pan-Africanism, giving this potentially abstract concept a range of palpable if ephemeral cultural forms, facilitating concrete encounters between Africans and members of the diaspora in which a profound sense of cultural belonging was performed. For all its flaws, FESMAN 2010 offered similar possibilities and I would argue that Tobias Wofford's reading of Dakar 1966 'as a site for a dialogue about the possibility of creating a global blackness' $(2009,186)$ is equally applicable to the later event. Both festivals were an occasion to question, challenge, debate, explore rather than simply to assert or passively accept various conceptions of a global black identity/community. Dominant accounts of the festivals read them through a lens of epistemic closure - 1966 was a celebration of Negritude, FESMAN was a chaotic disaster-but the reality of these events is that their impact is felt and their archival trace is visible in complex and unpredictable ways long after the show has ended. This can take the form of recuperation and nostalgia but this does not mean that we can simply dismiss the utopian possibilities of these performances of Pan/pan-Africanism. 


\section{References}

Apter Andrew. 2005. The Pan-African Nation: Oil and the Spectacle of Culture in Nigeria. Chicago and London: University of Chicago Press.

Boukari-Yabara, Amzat. 2014. Africa Unite! Une histoire du panafricanisme. Paris: La Découverte.

De Jong, Ferdinand, and Vincent Foucher. 2010. 'La Tragédie du Roi Abdoulaye? Néomodernisme et renaissance africaine dans le Sénégal contemporain.’ Politique africaine 118: 187-204.

De Jong, Ferdinand, and Brian Quinn. 2014. 'Ruines d'utopies: L'Ecole William Ponty et L’Université du Futur Africain.' Politique Africaine, 135: 71-93.

Derrida, Jacques. 1996. Archive Fever: A Freudian Impression. Chicago: University of Chicago Press.

Dovey, Lindiwe. 2015. Curating Africa in the Age of Film Festivals. London: Palgrave Macmillan.

Du Bellay, Joachim. 2015 [1549]. Défense et illustration de la langue française. Paris: FB Editions.

Ekpo, Denis. 2008. 'Festac 77 et le projet de modernité africaine: des méfaits d'un nationalisme culturel excessif', Africultures, 74: 26-34.

Flather, Newell. 1966. 'Impressions of the Dakar Festival.' Africa Report (May): 57-60.

Gonzales, Sérigne Ndiaye, 2010. 'Ce festival est celui de la honte'. La Sentinelle: 15-16 December, 4-5.

Jaji, Tsitsi Ella. 2014: Africa in Stereo: Modernism, Music, and Pan-African Solidarity. Oxford: Oxford University Press. 
Jaji, Tsitsi Ella. 2016: “"The Next Best Thing to Being There”: Covering the 1966 Dakar Festival and its Legacy in Black Popular Magazines.' In Murphy (ed.), The First World Festival of Negro Arts, Dakar 1966, XX-XX.

Joachim, Paulin. 1966a. 'La Négritude, connais pas.' Bingo 161 (June): 11.

Joachim, Paulin. 1966b. ‘Où va la culture négro-africaine?' Bingo 161 (June): 13-15.

Malaquais, Dominique, and Cédric Vincent, 2016. 'PANAFEST: A Festival Complex

Revisited.' In Murphy (ed.), The First World Festival of Negro Arts, Dakar 1966, XX$\mathrm{XX}$.

Murphy, David. 2009. 'Léopold Sédar Senghor: Race, Language, Empire.' In Postcolonial Thought in the French-Speaking World, ed. by Charles Forsdick and David Murphy, 157-70. Liverpool: Liverpool University Press.

Murphy, David. 2011. 'Renaissance Men? Behind the Scenes at the Festival Mondial des Arts Nègres (Dakar, 10-31 December 2010).' Bulletin of Francophone Postcolonial Studies 2 (1): 2-6.

Murphy, David. 2014. 'Sport, Culture and the Media at the Festival Mondial des Arts Nègres de Dakar (2010): sport and the democratization of culture or sport as populism?' French Cultural Studies, 25 (1): 10-22. Special issue: 'Sport, media and identity'.

Murphy, David. 2015. 'Culture, Development, and the African Renaissance: Ousmane Sembène and Léopold Senghor at the World Festival of Negro Arts (Dakar 1966).' In Ousmane Sembène and the Politics of Culture, ed. by Amadou T. Fofana and Vetinde Lifongo, 1-16. Lanham, MD: Lexington.

Murphy, David (ed.). 2016. The First World Festival of Negro Arts, Dakar 1966: contexts and legacies. Liverpool: Liverpool University Press. 
Neveu Kringelbach, Hélène. 2016. 'Dance at the First World Festival of Negro Arts: Of “fabulous dancers" and Negritude undermined.' In Murphy (ed.), The First World Festival of Negro Arts, Dakar 1966, XX-XX.

Pool, Hannah. 'World Festival of Negro Arts: a once in a decade event', The Guardian, 3 January.

Premier festival mondial des arts nègres [festival programme]. 1966. Paris: Impressions André Rousseau.

Premier festival mondial des arts nègres [livre d'or du festival]. 1967. Paris: Imprimerie Bouchet-Lakara.

Rous, Jean. 1967. Léopold Sédar Senghor: la vie d'un président de l'Afrique nouvelle. Paris:

J. Didier.

Sylla, Abdou. 2007. 'La tumultueuse histoire du Musée dynamique de Dakar', Africultures, 70: 89 .

Wilder, Gary. 2015: Freedom Time: Negritude, Decolonization and the Future of the World. Durham, NC: Duke University Press.

Wofford, Tobias. 2009. 'Exhibiting a Global Blackness: The First World Festival of Negro Arts'. In New World Coming: The Sixties and the Shaping of Global Consciousness, ed. by Karen Dubinsky et al., 179-86. Toronto: Between the Lines.

\footnotetext{
${ }^{1}$ For an overview of the festival, see Murphy (2016). This volume offers detailed analysis of various strands of the festival, which it is beyond the scope of the present article to provide. ${ }^{2}$ Alioune Diop, founder of the Paris-based publishing house Présence Africaine, was the official chair of the organizing committee but Senghor was the figure that did most to promote the specific cultural vision at the heart of the festival.
} 
${ }^{3}$ For a more in-depth discussion of Senghor's historical understanding of African culture, see Murphy 2009, 157-70.

${ }^{4}$ For an in-depth discussion of the attempt to recuperate Sembene at the 1966 festival, see Murphy (2015).

${ }^{5}$ This information is taken from an undated Los Angeles Times clipping contained in the Mercer Cook Papers, Box 157-18, File 5 at the Moorland-Springarn Research Center, Howard University, Washington, DC.

${ }^{6}$ For an outline of the exhibition, see www.quaibranly.fr/en/exhibitions-and-events/at-themuseum/exhibitions/event-details/e/dakar-66-36335 (consulted on 27 February 2016).

7 To view some of the material from the project, visit: http:// http://www.iiac.cnrs.fr/article477.html (consulted on 27 February 2016).

${ }^{8}$ On the Monument de la Renaissance Africaine, see De Jong and Foucher (2010). De Jong and Quinn trace a similar process of positing deep historical roots and projecting towards the future in Wade's (failed) attempts to restore the Ecole William Ponty, at which he and other members of the Francophone West African colonised elite were trained, while nearby he began the construction of the Université du Futur Africain, a development that ran out of funding and remains an unfinished building site (see De Jong and Quinn 2014).

9 The unreliability of the programme as archive is illustrated by the case of a US-based scholar with whom I am acquainted. In late 2010, she received an invitation to give a paper at the 'conférence structurante' and, several weeks after the festival, received a note from the organizers thanking her for her contribution: unfortunately, she had not in between these two missives either received her airline ticket or actually attended the conference. For an account of the often chaotic experience of attending the festival, see Murphy (2011).

${ }^{10}$ For a brief history of the museum's troubled history, see Sylla (2007). 